\title{
Evidences of volcanic unrest on high-temperature fumaroles by satellite thermal monitoring: The case of Santa Ana volcano, El Salvador
}

\author{
M. Laiolo a,b,*, D. Coppola b, F. Barahona ${ }^{\mathrm{c}}$, J.E. Benítez, C. \\ Cigolini b,d, D. Escobar $^{\text {e }}$, R. Funes ${ }^{\text {c }}$, E. Gutierrez ${ }^{\text {e }}$, B. Henriquez \\ ${ }^{\text {c }}$, A. Hernandez ${ }^{\text {c }}$, F. Montalvo ${ }^{\text {e }}$, R. Olmos ${ }^{\text {c }}$, M. Ripepe ${ }^{\text {a }}$, A. Finizola ${ }^{\text {f }}$ \\ a Dipartimento di Scienze della Terra, Università di Firenze, Via G. La Pira 4, 50121 Firenze, Italy \\ b Dipartimento di Scienze della Terra, Università di Torino, Via Valperga Caluso, 35, 10125 Torino, Italy \\ c Instituto de Ciencias de la Tierra, Universidad de El Salvador (UES), San Salvador, El Salvador \\ ${ }^{\mathrm{d}}$ NatRisk, Centro Interdipartimentale per $i$ Rischi Naturali, Università di Torino, Italy \\ e Observatorio Ambiental del Ministerio de Medio Ambiente y Recursos Naturales (MARN), San Salvador, El Salvador \\ f Laboratoire GéoSciences Réunion, Université de La Réunion, IPGP, UMR 7154, CNRS, Sorbonne Paris Cité, La Réunion, France
}

\section{A B S T R A C T}

On October 1st, 2005, Santa Ana volcano (El Salvador) underwent a VEI 3 phreatomagmatic eruption after ap-proximately one century of rest. Casualties and damages to some of the local infrastructures and surrounding plantations were followed by the evacuation of the nearby communities. The analysis of MODIS (Moderate Res-olution Imaging Spectroradiometer) infrared data reveals that the main explosion was preceded by a one-year-long thermal unrest, associated to the development of a fumaroles field, located at the western rim of the summit crater lake. By combining space-based thermal flux and ground-based measurements (seismicity, sulfur emis-sions and lake temperatures), we suggest that the activity observed at Santa Ana between 2004 and 2005 was driven by the gradual intrusion of an undegassed magma body at a very shallow depth. Magma injection induced thermal anomalies associated with sustained degassing from the fumaroles field and promoted the interaction between the magmatic-hydrothermal system and the overlying water table. This process culminated into the VEI 3 phreatomagmatic eruption of October 2005 that strongly modified the shallow structure of the crater area. The subsequent three-years-long activity resulted from self-sealing of the fracture system and by the open-ing of a new fracture network directly connecting the deeper hydrothermal system with the crater lake. Our re-sults show that satellite-based thermal data allow us to detect the expansion of the high-temperature fumarolic field. This may precede an explosive eruption and/or a lava dome extrusion. In particular, we show that thermal records can be analyzed with other geochemical (i.e. $\mathrm{SO}_{2}$ emissions) and geophysical (seismicity) data to track a shallow magmatic intrusion interacting with the surrounding hydrothermal system. This provides a remarkable support for volcano monitoring and eruption forecasting, particularly in remote areas where permanent ground data acquisition is hazardous, expensive and difficult.

\section{Introduction}

Thermal monitoring of a fumarolic area is a key tool to track changes in hydrothermal systems which lay in the surrounding of magma bodies (Chiodini et al., 2007; Shinohara et al., 2015; Fischer et al., 2015; Ricci et al., 2015). Intense degassing, characterized by a marked fumarole activ ity, is usually associated with variations in volcanic activity (e.g. phreatic eruptions) which, in turn, may coexist with the extrusion (and/or grow ing cycles) of a lava dome (Barberi et al., 1992; Kaneko and Wooster, 1999; Stevenson and Varley, 2008; Ball et al., 2013; Phillipson et al.,

\footnotetext{
* Corresponding author at: Dipartimento di Scienze della Terra, Università di Firenze, Via G. La Pira 4, 50121 Firenze, Italy.

E-mail address: marco.laiolo@unito.it (M. Laiolo).
}

2013). On the whole, fumaroles hosted within or around a crater lake may show signs of volcanic unrest. These are generally coupled with chemical variations in fluid composition and color changes of the water lake (Németh et al., 2006; Shinohara et al., 2015; Fischer et al., 2015).

Although satellite thermal data have been increasingly used to mon itor active volcanoes (Ramsey and Harris, 2012; Harris, 2013; Coppola et al., 2016a), the detection of small thermal anomalies (e.g. lacking of a di rect magma exposure at the surface) remains a rather challenging task in volcanology (cf. Coppola et al., 2016b). In fact, fumaroles and other low thermal signals are cooler (when compared with magma tempera tures), and smaller (with respect to hot lava flows and domes). Howev er, high spatial resolution sensors (TM class sensor with $3090 \mathrm{~m}$ pixel resolution; cf. Harris, 2013 classification), recording data in the Thermal 
InfraRed (TIR) region of the electromagnetic spectrum, have been gen erally used to collect systematic measurements (Oppenheimer, 1993, 1996, 1997; Trunk and Bernard, 2008; Bodruddoza Mia et al., 2014). However, despite these results being reliable and encouraging, TM class sensors provide data with a relatively poor temporal resolution ( 16 days at most) and may miss short term fluctuations or the detec tion of important events (i.e., at their onset). Conversely, the AVHRR class sensors may provide several images per day (with $1 \mathrm{~km}$ pixel res olution on IR bands; see Harris, 2013 classification) and have greatly im proved the capability to detect and track remote eruptive events (Dean et al., 1998; Dehn et al., 2002; Patrick et al., 2005) as well as to identify hot fumaroles activity (Vulcano Island; Harris and Stevenson, 1997). In particular MODIS (Moderate Resolution Imaging Spectroradiometer) data, providing four overpasses per day at the equator, represents a valuable tool for detecting low magnitude thermal anomalies on poorly monitored and/or remote active volcanoes (Coppola et al., 2015, 2016b, 2016c).

In this paper, we present the thermal activity at the Santa Ana volca no achieved by processing the 20002015 dataset of nighttime MODIS images with the MIROVA algorithm (cf. Coppola et al., 2016a). The re trieved thermal flux jointed with ground based data (performed by the UES Universidad de El Salvador and the MARN Observatorio Ambiental del Ministerio de Medio Ambiente y Riesgos Naturales) allowed us to draw a reliable timeline of the unrest phases which were preceding the major explosion of Santa Ana on October 1st, 2005. Our results delineate the complex relationships occurring among the shal low level magma body, hydrothermal degassing and crater lake activity.

\section{Santa Ana volcano}

Santa Ana $\left(13^{\circ} 51^{\prime} \mathrm{N}, 89^{\circ} 37^{\prime} \mathrm{W}\right)$ is the most active volcano of El Salva dor and one of the main of the Central America. The $2381 \mathrm{~m}$ high Santa
Ana volcano (locally named Ilamatepec), is part of the Coatepeque Izal co Santa Ana volcanic complex that lies at the intersection of the NW SE regional faults system and the southern rim of the so called Median Trough depression of Plio Pleistocene age (Fig. 1a; Mooser et al., 1958; Pullinger, 1998).

At least 12 eruptive episodes occurred at Santa Ana volcano since the 16 th century. These events were mainly characterized by phreat ic and phreatomagmatic eruptions (VEI 2 3; Simkin and Siebert, 1994) and were sporadically accompanied by lava flow outpouring from the summit or from secondary cones aligned NW SE (Pullinger, 1998).

The summit part of the Santa Ana volcano consists of four concen tric craters, the largest one reaching a diameter of $1.5 \mathrm{~km}$, and the in nermost one (on the SE) with a radius of about $0.5 \mathrm{~km}$ (Fig. 1b, c). This latter is the youngest and was formed after the 1904 eruption (Carr and Pointer, 1981). It hosts an acidic crater lake with a chemical composition that reflects the interaction between the magmatic, hydro thermal and phreatic systems (Bernard et al., 2004; Scolamacchia et al., 2010).

In terms of risk assessment, it must be emphasized that nearly 1 mil lion of people live within an area with an approximate radius of $25 \mathrm{~km}$ from the summit crater. This drastically increases the hazard due to the occurrence of lahars and ash falls, capable of seriously damaging local infrastructures and agriculture (Pullinger, 1998).

No sign of volcanic activity has been noticed for Santa Ana since the 1904 eruption (Mooser et al., 1958; Bernard et al., 2004). However, since 2000 , the western sector of the crater lake was periodically surrounded by a high temperature fumarolic area (see Fig. 1b, d), testi fying the existence of a shallow, well developed hydrothermal system (Bernard et al., 2004; Rodríguez et al., 2004). The increase in the hydro thermal activity was marked by an intense degassing and glowing fu maroles (from $550{ }^{\circ} \mathrm{C}$ to $875^{\circ} \mathrm{C}$ ), as well as by changes in the water
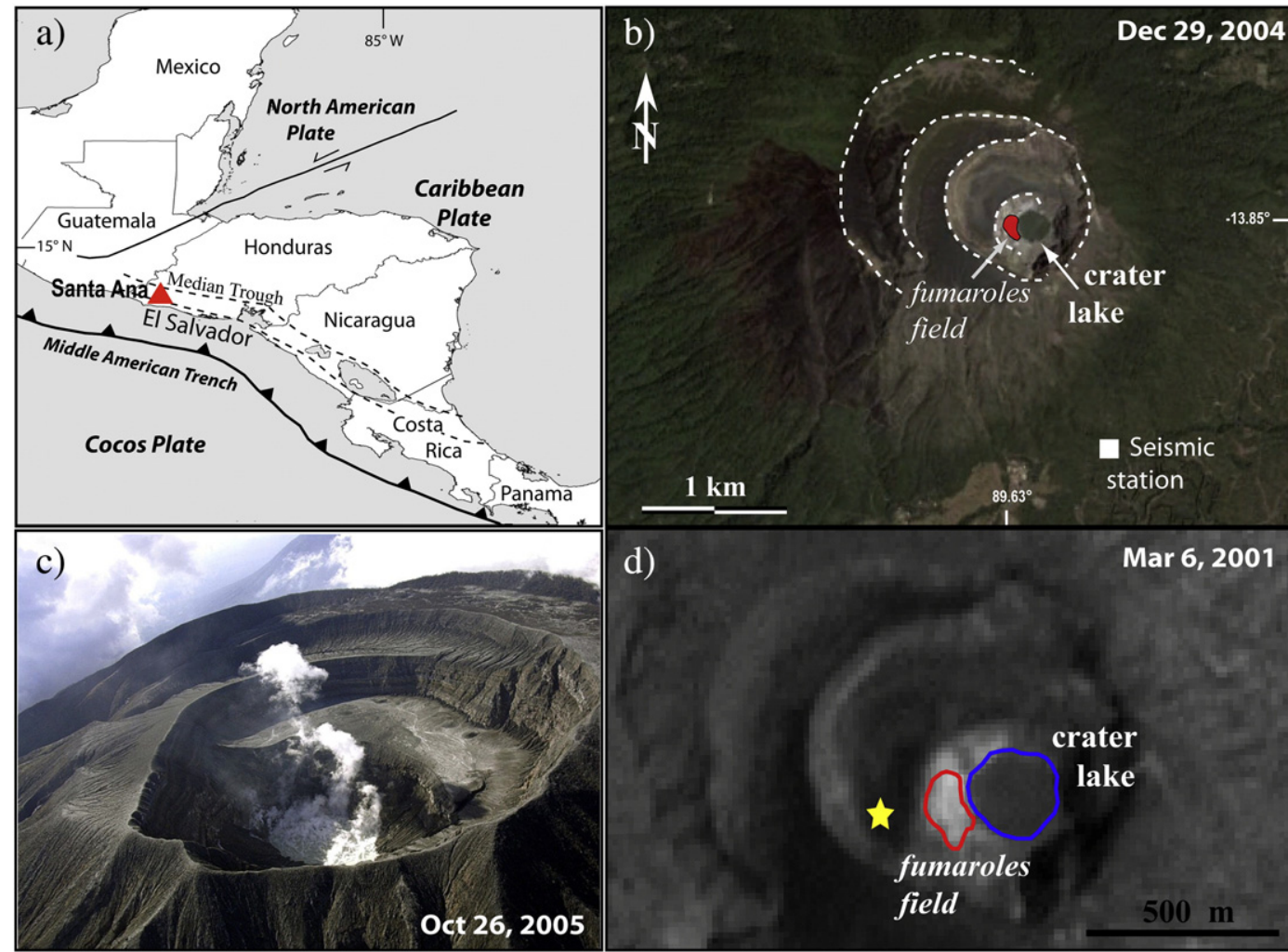

d)

$\operatorname{Mar} 6,2001$

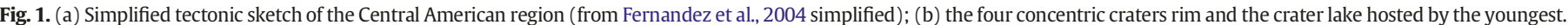

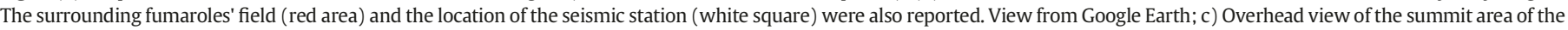

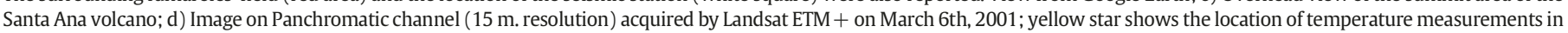
the fumaroles' field (see text for details). 
temperature of the lake (from $18{ }^{\circ} \mathrm{C}$ to $30^{\circ} \mathrm{C}$ ) (cf. Bernard et al., 2004; Global Volcanism Program, 2001). Thereafter, the Santa Ana volcano has shown progressive signs of unrest that culminated into the VEI 3 ex plosion of October 1, 2005 (Colvin et al., 2013).

After this major event, the activity was focused exclusively into the crater lake and consisted of evaporation cycles, increases in water lake temperatures, physico chemical changes and sporadic phreatic explo sions (Hernández et al., 2007; Colvin et al., 2013). Since early 2008, the Santa Ana summit lake seems to have entered in a relative quiet phase, defined by the stability in color, volume and temperature of the water lake (cf. Colvin et al., 2013). Here, we focus on a multiparametric analysis of the activity characterizing the Santa Ana volcano between 2004 and 2007, with a special emphasis on the unrest phase preceding the October 1, 2005 explosion.

\section{Datasets}

The datasets used in this paper consist of: $i$ ) Volcanic Radiative Power; ii) $\mathrm{SO}_{2}$ flux, iii) tremor amplitude (in terms of RSAM); (iv) daily number of the Long Period and $(v)$ daily number of Volcano Tec tonic events and (vi) crater lake temperature (Fig. 2).

\subsection{Space based thermal data the MIROVA algorithm}

MIROVA (Middle InfraRed Observation of Volcanic Activity; see Coppola et al., 2016a) is a global volcanic hotspot detection system that combines a moderate temporal and spatial resolution (4 images per day; $1 \mathrm{~km}$ pixel resolution) with a high efficiency in detecting small hotspots $(\sim 1 \mathrm{MW})$. These features enable the system to locate

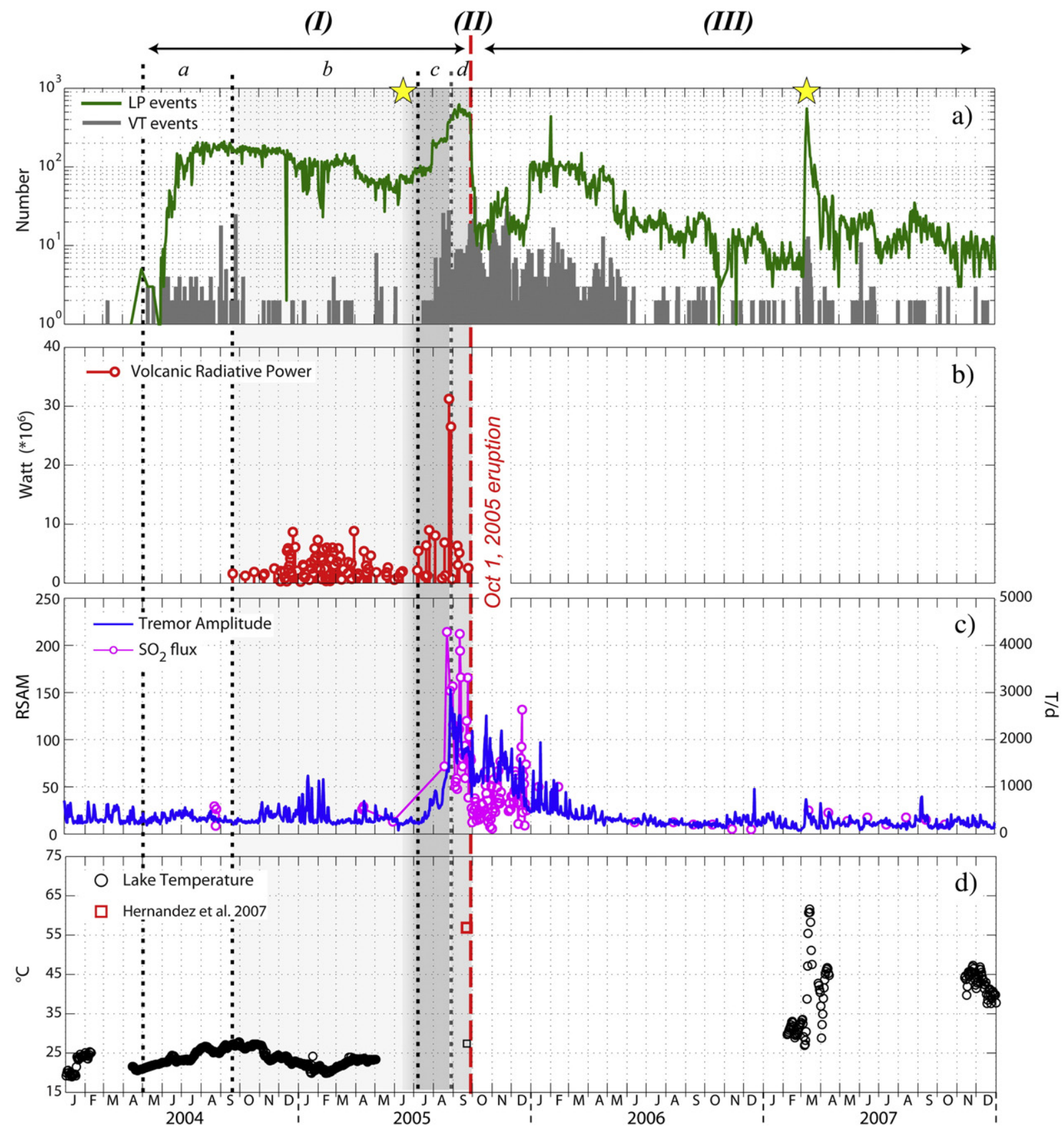

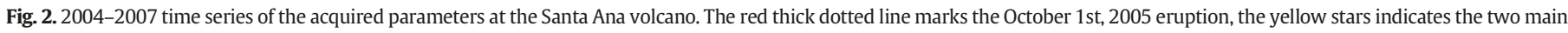

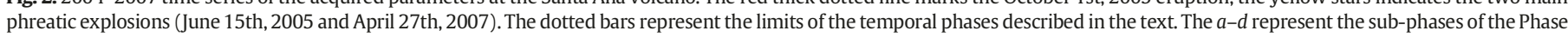
I (Unrest state). 
and quantify the heat generated by a large variety of volcanic activities on a daily basis (www.mirovaweb.it).

MIROVA uses Middle InfraRed (MIR) data acquired by Moderate Resolution Imaging Spectroradiometer (MODIS) sensor, mounted on board of Terra and Aqua NASA's satellites (launched on February 2000 and May 2002, respectively). The MODIS images $\left(1 \mathrm{~km}^{2}\right.$ of resolution in the IR bands), are automatically processed by a hybrid algorithm, where each single image is managed to: (i) produce $50 \times 50 \mathrm{~km} \mathrm{NTI}$ maps centered on the volcano summit; (ii) detect the presence of sub pixel, high temperature hot spot(s), and (iii) quantify the Volcanic Ra diative Power (VRP in Watt) associated to the hot source (see Suppl. Materials; Coppola et al., 2016a).

\subsection{Seismic measurements}

Seismicity was detected on a telemetered seismic station equipped with an LLC Short period Seismometer Model S 13/GS 13 (Geotech In struments), vertical component maintained by SNET technics. During the analyzed period, high frequency Volcano Tectonic (VT) and Long Period (LP) events were registered and related to the summit activity of the Santa Ana volcano. Tremor amplitude was elaborated in terms of RSAM (Real Time Seismic Amplitude Measurements) by considering a value of 20 units as the baseline for the analyzed area (cf. Olmos et al., 2007).

\section{3. $\mathrm{SO}_{2}$ flux measurements}

The daily $\mathrm{SO}_{2}$ were obtained by a NOVAC Scanning DOAS system (Scanning Dual beam miniature Differential Optical Absorption Spec troscopy system) (Galle et al., 2002). The instrument is composed of one miniaturized spectrometer (Ocean Optics Inc.), embedded PC, an optical fiber, a telescope and a GPS receiver. The Optic Spectrometer de tects UV (ultraviolet) light and converts it to digital signals. The signals are the spectra for later gas evaluation. The telescope collects the ultra violet light scattered from aerosols and molecules in the atmosphere. Controlled by the motor, it is able to turn in $360^{\circ}$. The optical fiber trans fers light from the telescope to the spectrometer. The motor controls the angle of the telescope. It moves the telescope to perform certain steps, according to the command from the embedded PC. The GPS receiver re cords the position of the system and gives out the universal standard time. The embedded single chip PC collects the spectra and manages communication.

\subsection{Lake temperature measurements}

Lake temperature has been measured every $24 \mathrm{~h}$ with digital Logger sensor thermometers (range: $-20+50{ }^{\circ} \mathrm{C}$ and accuracy of $\pm 0.4{ }^{\circ} \mathrm{C}$ ) placed in the middle of the lake, at a depth of $1 \mathrm{~m}$. Due to the difficulty experienced to maintain the efficiency of this set up instrumentation in an area such as the summit of Santa Ana volcano, the reported dataset suffered some long time period data gaps.

\section{The 20042007 eruptive activity at Santa Ana volcano}

Here we combine the satellite thermal data, obtained by using the MIROVA system, with the geophysical and geochemical parameters ac quired by the U.E.S. and M.A.R.N. at the Santa Ana volcano between 2004 and 2007 (Fig. 2). Visual observations and periodic field surveys on the summit area (see Figs. 3, 6) have been used to describe the sum mit activity and to support the interpretation of the monitored parameters.

On the whole, the analyzed period has been subdivided into three main phases that include: (i) a phase of volcanic unrest (2004 2005), culminated with (ii) the VEI 3 October 1st, 2005 phreatomagmatic ex plosion that was followed by (iii) a period of frequent physico chemical changes of the crater lake (2006 2008) coupled with sporadic phreatic explosions (cf. Colvin et al., 2013). Particularly, the combined analysis of the seismic, thermal and geochemical data allows us to follow the evo lution of the eruptive crisis and to subdivide the initial unrest phase into four distinct sub phases (Ia to Id) (Figs. 2 and 5).

\subsection{Phase I (June 1st, 2004 September 30th, 2005): unrest}

Until the end of May 2004, the Santa Ana volcano had exhibited a lack of seismicity, absence of space based thermal anomalies, with the crater lake temperature spanning between 18 and $25^{\circ} \mathrm{C}$ and relatively stable $\mathrm{SO}_{2}$ emissions of below 600 T/d (see Fig. 2; Colvin et al., 2013).

\subsubsection{Phase Ia (June 1st, 2004 September 20th, 2004)}

Since June 2004 (Phase Ia), we started to record Long Period (LP) events and volcano tectonic (VT) swarms, indicating that the Santa

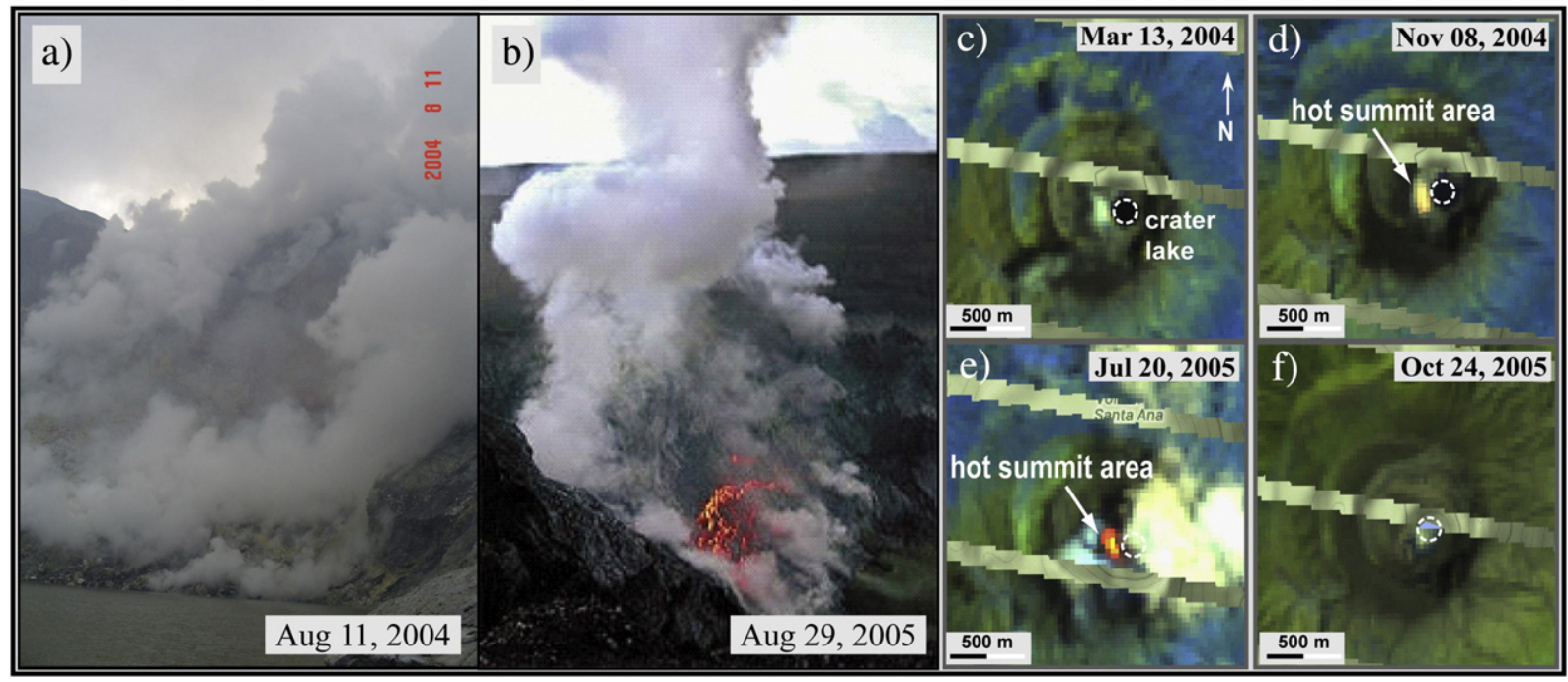

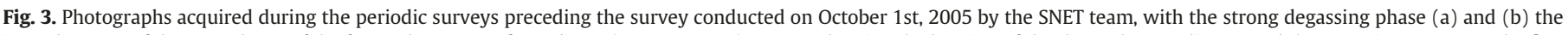

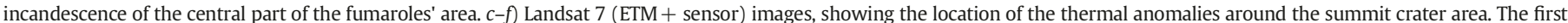

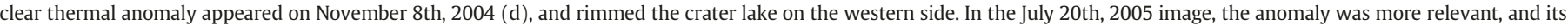

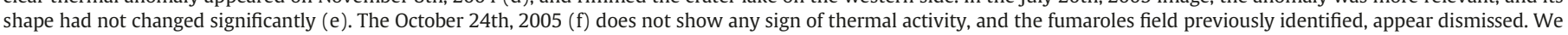
combined Band 7 (Mid infrared), Band 5 (Near infrared) and Band 4 (Near infrared) into the RGB. 
Ana volcano was entering into a "seismic unrest" phase. Notably, both signals define a marked increasing trend with time, mainly highlighted by the records of long period (LP) daily rate until August 2004 (cf. Fig. $2 a)$.

\subsubsection{Phase Ib (September 21st, 2004 July 7th, 2005)}

On September 21st, 2004 the first genuine thermal alert (1.6 MW) was detected by the MIROVA system. This "thermal unrest" phase persisted for about one year and, since then, coexisted with the anoma lous seismic activity (Fig. 2b). Since this first detection, the MODIS data define a nearly constant increase in the number and magnitude of ther mal anomalies that, during the January April period, was coupled with a relatively slight enhancement in tremor amplitude (Fig. 2b, c). High resolution Landsat $(\mathrm{ETM}+$ ) images (see Fig. 3c f), indicate that these MODIS derived thermal anomalies were originating from a high tem perature and strong degassing fumaroles' field (located on the western rim of the summit crater lake). In spite of the persistence of moderately high level of activity at the adjacent fumaroles (e.g. degassing), no sig nificant anomalous signals were observed in the temperature of the water lake (Fig. 2d; Colvin, 2008; Olmos et al., 2007).

Periodic measurements of fumarolic temperature (between 14th and 18th June 2005) recorded a sudden increase, from $84{ }^{\circ} \mathrm{C}$ to $95{ }^{\circ} \mathrm{C}$ (Fig. 4), that was preceded by the Jun 15th, 2005 phreatic eruption. This event was characterized by intense gas emissions, moderate ejec tion of blocks and the deposition of a $1 \mathrm{~mm}$ thick ash layer at the north ern sector of the volcano (SNET Informes Especiales, 2005a, b). This event did not produce immediate structural changes at the summit, al though it was the first explosion during the analyzed unrest phase. Since then, we observe a general, marked increase at all the monitored parameters (Figs. 2 and 5) and we regard the June 15th explosion as a key episode, which promoted the connection between the magmatic hydrothermal system and the surface fumarolic field.

\subsubsection{Phase Ic (July 8th, 2005 August 30th, 2005)}

The July August 2005 period is characterized by a general growth of both LP and VT events as well as by the increased thermal flux (VRP), tremor amplitude (RSAM) and $\mathrm{SO}_{2}$ degassing (Fig. 5). In particular, we fix the onset of this phase with the sharp increase in thermal activity, initially being higher than $10 \mathrm{MW}$ (never observed before) and culmi nating, on August 27th, 2005 (at 04:05 UTC time), up to 31 MW.
Notably, between the August 24th and 30th, 2005, the $\mathrm{SO}_{2}$ flux (4285 T/d), thermal flux (31 MW) and tremor amplitude (154 cts) reached peak values. Field surveys on August 29th, 2005 indicated that the fumaroles' area was affected by incandescence (hot cracks; $\sim 200 \mathrm{~m}^{2}$ ) and intense degassing activity (cf. Fig. 3b; SNET Informe Especial, 2005c).

By the end of August 2005, volcanic activity entered into a critical phase, when thermal, degassing and seismic parameters (RSAM) reached their peak values since the first signals of unrest. At that time, no physico chemical and thermal changes occurred at the crater lake, suggesting that its bottom was essentially sealed, and was not affected by the above perturbations. A similar phenomenon was observed by Casertano et al. (1987) at the Poás volcano during the winter of 1980; in this case also, there was an incandescence of the central dome with temperatures reaching $960^{\circ} \mathrm{C}$ ( preceded, four months prior, by intense seismicity) that did not affect the nearby water lake temperatures.

\subsubsection{Phase Id (August 31st September 30th, 2005)}

During September 2005, LP and VT events showed a further increase with a maximum of 622 LP events/day, recorded on September 12th (Fig. 5a, b). Conversely, the radiative power, tremor amplitude and $\mathrm{SO}_{2}$ flux followed a nearly coeval waning trend (Fig. $5 \mathrm{c}, \mathrm{d}, \mathrm{e}$ ) likely relat ed to a decrease in the activity of the fumaroles. The September 25th field thermal surveys did not show the existence of fresh magma at the surface. In turn, the water lake temperature increased, reaching its top value of $58{ }^{\circ} \mathrm{C}$ (Hernández et al., 2007; cf. Fig. 2d). Notably, the last satellite thermal detection (about $3 \mathrm{MW}$ ) occurred on September 26th, 2005, just five days before the main eruptive event of October 1 st, 2005.

\subsection{Phase II (October 1st, 2005): phreatomagmatic explosion}

After about 500 days from the onset of seismic swarms, at 08:30 a.m. of October 1st, 2005 a VEI 3 phreatomagmatic eruption (Global Volcanism Program, 2005) affected the summit area of the Santa Ana volcano. This major event caused the emission of about $15,000 \mathrm{~m}^{3}$ of ash (Global Volcanism Program, 2005) associated with the release of $12 \mathrm{kT}$ of $\mathrm{SO}_{2}$ into the atmosphere (Carn et al., 2016) and the develop ment of a $12 \mathrm{~km}$ high eruptive column (cf. Scolamacchia et al., 2010).

In the following days, heavy rainfalls, due to severe atmospheric per turbations associated with the arrival of hurricane Stan in the area,

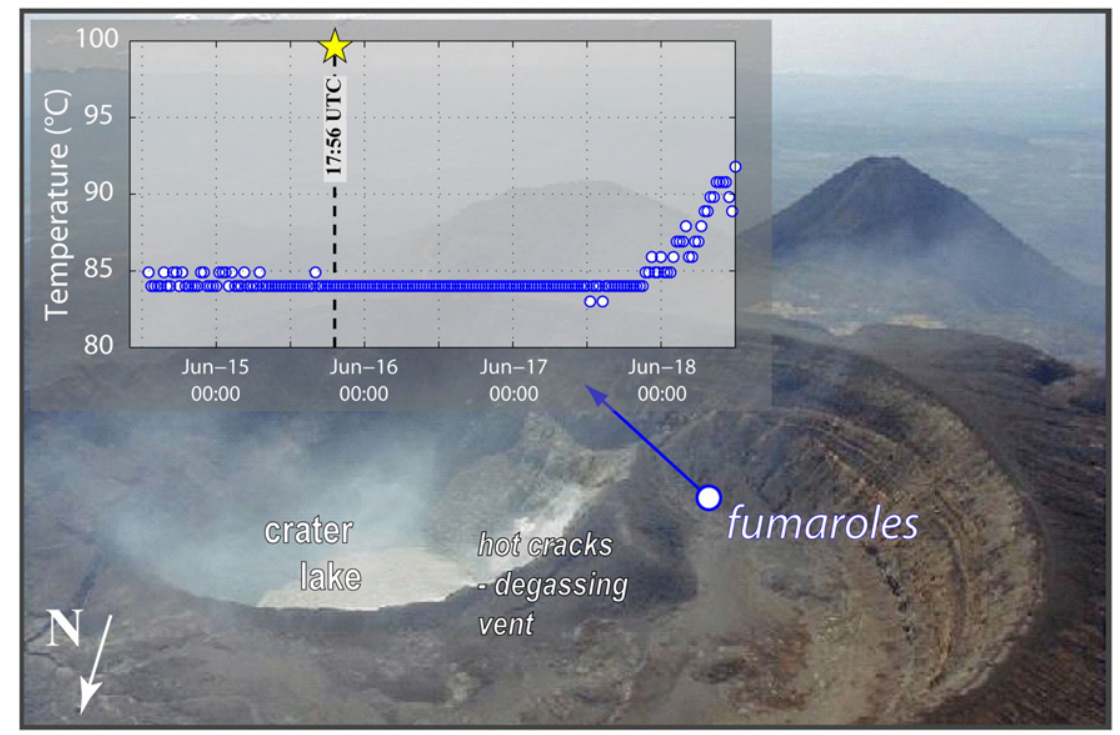

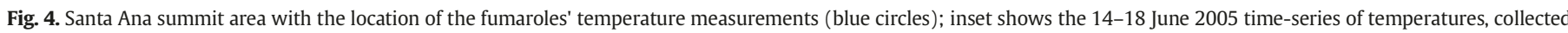
automatically. The dotted line with the yellow star marks the occurrence of the phreatic explosion. 

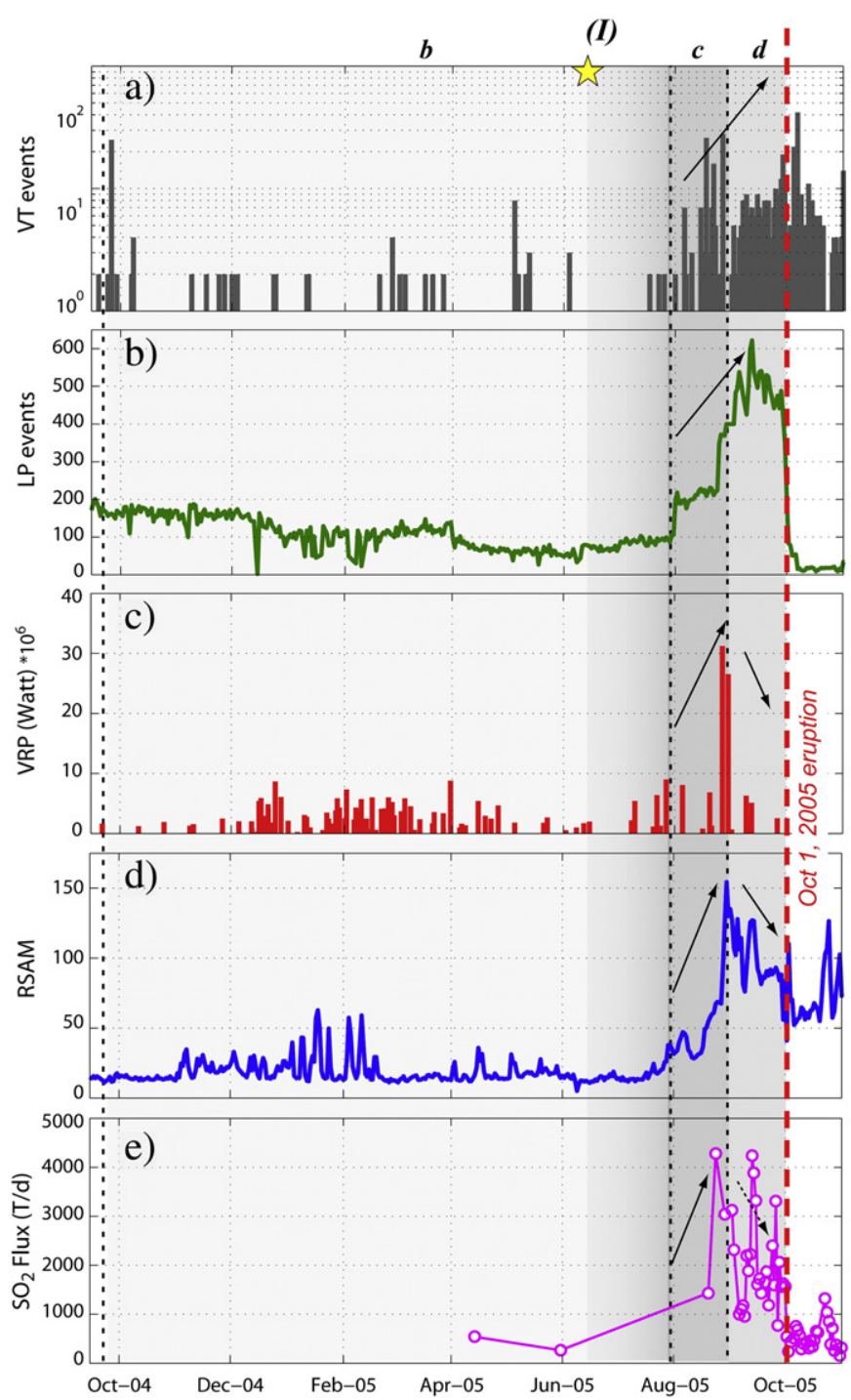

Fig. 5. Time series the main acquired parameters at the Santa Ana volcano during the September 2004 - October 2005 period. The dotted bars represent the limits of the recognized sub-phases, red line marks the October 1st, 2005 eruption and yellow star the June 15th, 2005 first phreatic eruption.

triggered several lahars and landslides onto the South East slope of the volcano which induced local authorities to evacuate about 5000 inhab itants (cf. Global Volcanism Program, 2005; Scolamacchia et al., 2010). Moreover, the hot lahars damaged the vegetation of the summit area, up to $35 \mathrm{~km}$ distance from the hilltop. The ash fallout affected the western sector of the cone, including the villages of Los Naranjos, La Majada and Apaneca (Olmos et al., 2007; Scolamacchia et al., 2010). As a whole, this event caused two deaths and the damage of about 1400 ha with a major impact on the local economy, essentially based on agriculture (Global Volcanism Program, 2005).

During this major phreatomagmatic explosion, the fumarolic area disappeared (cf. Fig. 3f) and the eruptive event drastically changed the morphology of the summit crater area (Hernández et al., 2007).

\subsection{Phase III (October 2, 2005 January 2008): crater lake activity}

After the October 1, 2005 explosion, summit activity was character ized by the total absence of thermal anomalies, and by a general decrease in seismicity and $\mathrm{SO}_{2}$ emissions which, however, were some how above background levels (cf. Fig. 2). Notably, the VEI 3 eruptive event was a prelude to the following crater lake's anomalous activity (cf. Rouwet et al., 2014) that characterized the Santa Ana volcano for about 3 years, with several phreatic explosions, physico chemical changes and drastic temperature variations within the summit lake (cf. Colvin et al., 2013).

In this period, the crater lake suffered several phases of instability with marked evaporation cycles (not related to daily and seasonal be havior) and minor phreatic explosions (Fig. 6). Until April 2006, the lake underwent visible evaporation processes (i.e., bubbling), leading to the decline of about 30\% of its volume on April 20, 2006 (with respect to the pre eruptive phase volume), coupled by changes in water color ation (Fig. 6a, b, c). Until September 2007, the crater lake cyclically suf fered strong modifications, particularly during March April, when the water lake reached temperatures above $50{ }^{\circ} \mathrm{C}\left(\max 67^{\circ} \mathrm{C}\right.$ the March 13rd, 2007; cf. Fig. 2d). The occurrence of minor phreatic explosions (e.g. March 15th and April 27th) was accompanied by a drastic decrease of the lake size, which, in the following month, reached to about $4 \%$ of its original volume (Fig. 6d, e, f). Since the end of 2007, the lake has shown a nearly stable temperature $\left(30{ }^{\circ} \mathrm{C}\right.$ on average) and has partially recov ered its pre eruptive volume (cf. Colvin et al., 2013). Currently, no anomalous activity has been recorded at the Santa Ana Volcano (SNET, 2017).

\section{Discussion}

So far, we outlined the temporal evolution of the monitored param eters before and after the October 1, 2005 phreatomagmatic eruption. To proceed, we will be discussing these topics in the attempt to link the observed volcanic processes with the problems of forecasting of eruptions at the Santa Ana. In this perspective, unrest phases have been tentatively linked with the intensity of volcanic processes occur ring before, during, and after the onset of the October 1, 2005 paroxysm, following the classification described by Potter et al. (2015).

\subsection{The Santa Ana volcano: from seismic unrest to crater lake activity}

The combined acquisition of ground and space based time series over a given volcanic area contributes to volcano surveillance and risk mitigation as well as to the better understanding of surface and deeper processes that drive the observed volcanic activity (cf. Coppola et al., 2017; Ripepe et al., 2015; Valade et al., 2016). The multiparametric dataset acquired at Santa Ana volcano, coupled with periodic surveys, give us the opportunity to reconstruct (Fig. 7) the migration of an undegassed magma batch toward the surface, as well as its effects on the hydrothermal system and the connected crater lake.

By analyzing the time evolution of the Santa Ana 20042005 activity, we link seismic unrest (VT swarms and the LP events) to the ascent of a magma batch (e.g. McNutt, 2000; Zobin et al., 2008; Cannata et al., 2013 ) that promoted crack propagation, substantial heat flow growth, and degassing (cf. Chouet and Matoza, 2013; Fig. 7a).

This process induced an increase in thermal activity (i.e. rock crack incandescence within the fumaroles field), tremor amplitude and $\mathrm{SO}_{2}$ flux (Fig. 7b, c). It is worth noting at this stage, that no physico chemical and thermal changes were observed (and/or recorded) within the cra ter lake, suggesting that it was still insulated (i.e., sealed) from the sur roundings, whereas the fumarole field was affected by anomalous degassing.

The increase in water temperature within the lake (Hernández et al., 2007) was observed only on September 2005 (i.e., about one year after the beginning of the unrest) and was accompanied by a decrease in tremor amplitude, sulfur outgassing and space detected thermal anom alies (cf. Figs. 2 and 7d).

\subsubsection{Magma hydrothermal system relationships}

Particularly during Phase Id (Figs. 5 and 7d), seismic activity (VT and LP events) was high, and it is generally known that this scenario may precede explosive episodes, such as phreatic and phreatomagmatic 

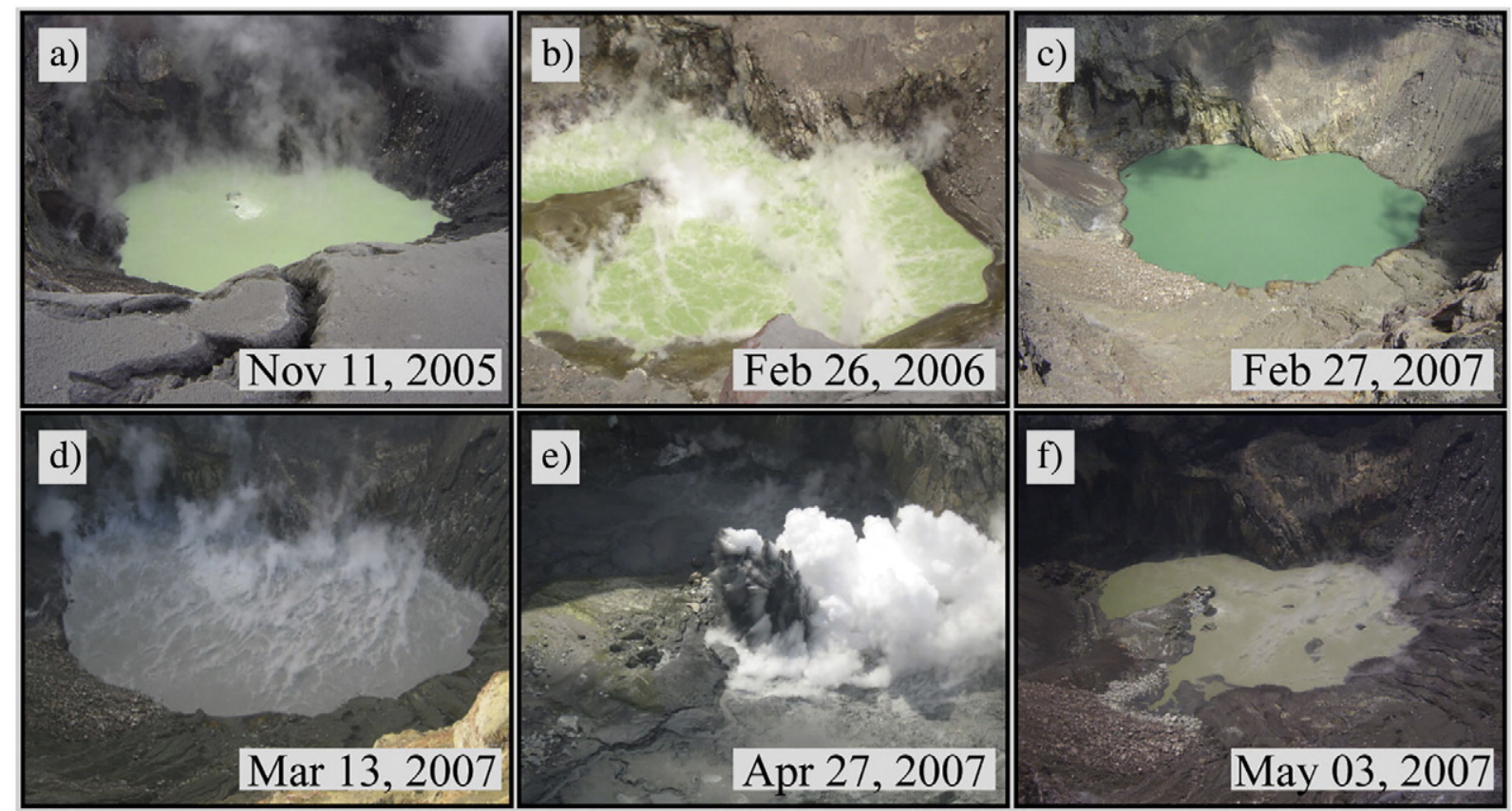

Fig. 6. A collection of photographs resuming the changes of Santa Ana crater lake, from November 2005 to May 2007. Frame 5e reports the phreatic blast of April 27 th, 2007.

eruptions (e.g. Ruapehu; cf. Christenson and Wood, 1993; Christenson et al., 2010). Indeed, the major phreatomagmatic eruption occurred on October 1, 2005 (VEI 3) (Fig. 7e). Likely, during its onset, a direct inter action between the magma and the hydrothermal system occurred, opening the fracture system that was previously sealed. Since then, cra ter lake activity has been operative for the following three years (cf. Olmos et al., 2007; Colvin et al., 2013; see Fig. 7f). The occurrence of ju venile andesitic to rhyolitic glass fragments in the erupted materials support the idea of a near surface ascent of a magma body during the October 1st episode (cf. Scolamacchia et al., 2010).

The phenomena observed at Santa Ana are comparable with those occurring at Poás (Laguna Caliente) and Asosan (Yadamari) which also host a summit lake with nearby high temperature fumarolic fields (cf. Fischer et al., 2015; Shinohara et al., 2015).

However, it is worth analyzing the transition of hydrothermal activ ity from the fumarole field to the crater lake. This process is substantially accomplished during Phase Id (Figs. 5 and 7d). Fluid motion, associated with previous, vigorous degassing contributed to the progressive sealing the fractures of the hydrothermal sector comprised between the magma body and the fumaroles. This dynamic typically occurs in volcanic hydrothermal systems due to the sustained fluid flux as noticed by Olmos et al. (2007) and Rosas Carbajal et al. (2016). This process is usually accompanied by a pervasive "argillification" of the wall rock (e.g., Williams Jones et al., 2000; Finizola et al., 2004). The coupling of the above mechanisms are able to prevent both heat transfer and gas flux toward the surface, thus generating an overpressure below the self sealed horizon (Casadevall et al., 1981; Cigolini et al., 2005; Cigolini, 2010).

In our specific case, the increase in seismic activity (i.e., Phase Ic $d$; see Fig. 5) associated with the migration of the magma body, likely in duced fracturing of the low permeable rock layer that typically under lay a crater lake (Colvin, 2008). In turn, the opening of the fracture system depressurized the stored magma that interacted with the water table, triggering the phreatomagmatic eruption (Phase II). The fol lowing period (Phase III), characterized by "peak/high level activity" of the crater lake (e.g., Rouwet et al., 2014), eventually associated with phreatic eruptions, is consistent with the above setting, when the fuma roles' field is dismissed and the fluid flux is concentrated within the summit lake (cf. Tassi et al., 2009). Notably, a similar mechanism has been recently suggested for the 20002008 activity at Poás volcano (Fischer et al., 2015).

Likewise, at the Santa Ana volcano, the gas release from magma may cause the partial or complete sealing of the fractures network below the fumaroles that, however, promote, due to the pressure, the disruption, and the fracturing of the rock layer below the lake. This scenario favored the interaction between the intruded magma body and the lake, as tes tified by the consequent setting $\mathrm{c}$ in the lake.

\subsection{Timeline of the volcanic unrest}

As recently reported (cf. Phillipson et al., 2013), the timeline of the events that occurred at the Santa Ana volcano can be considered a refer ence case for analyzing unrest levels on active volcanoes. In fact, the 20042005 scenario is overlapping the five level scale of Volcanic Un rest Index (V.U.I.) proposed by Potter et al. (2015), where each level was characterized by a peculiar observed and/or measured activity. In fact, we may notice that approaching the Oct 1, 2005 eruption, Santa Ana shifted from level 1 (Negligible) to level 4 (Heightened) during its unrest. In Fig. 8, we graphically reconstruct the link between the unrest level and the evolution of the events. The entering on an unrest state is typically heralded by seismic swarms, which is considered a long term (up to years) precursor of eruptions (cf. Phillipson et al., 2013; White and McCausland, 2015). At Santa Ana volcano, space based thermal anomalies had appeared more than one year prior (375 days) the Octo ber 1, 2005 explosion (Fig. 8). This is a striking novelty considering that, historically, the thermal anomalies have been substantially regarded as a short time precursor (8 days, on average; cf. Phillipson et al., 2013).

Although we likely consider the one year long Santa Ana thermal unrest a quasi unique case of long time high fumarolic activity capable to be detected by satellite observations, an additional and remarkable result is that the MIROVA algorithm was particularly efficient in identi fying low thermal anomalies. We stress that during the Santa Ana unrest phase, the magma body was confined at depth, and the thermal anom alies where essentially due to high temperature magma related fluids ascending through hot cracks. Hence, as per the sporadic 20012002 recorded thermal anomalies (cf. Supplementary Material), no magma reached the surface. As a whole, such as at the Santa Ana volcano, an in tense fumaroles' activity may precede explosive eruption phases and/or 


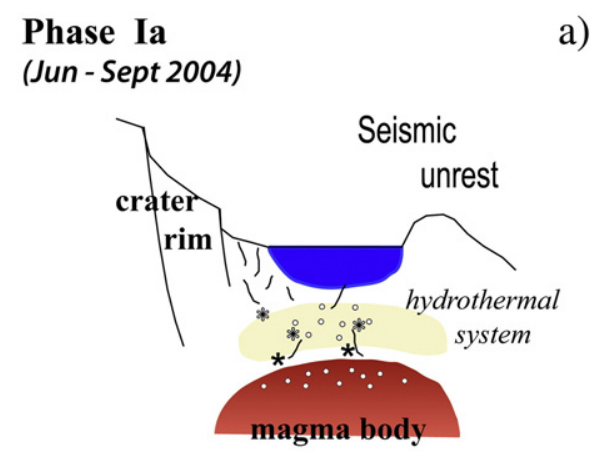

a)

Phase Id

(Sept 2005)

d)

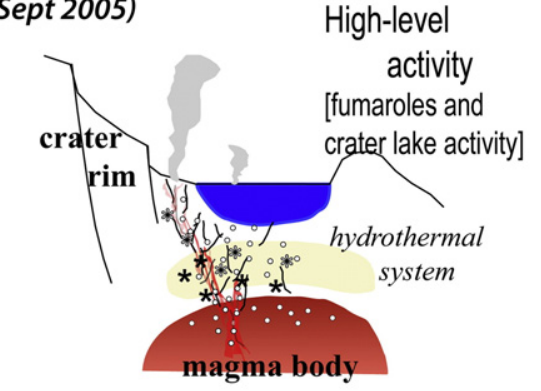

Phase Ib

(Sept 2004 - Jun 2005)

b)

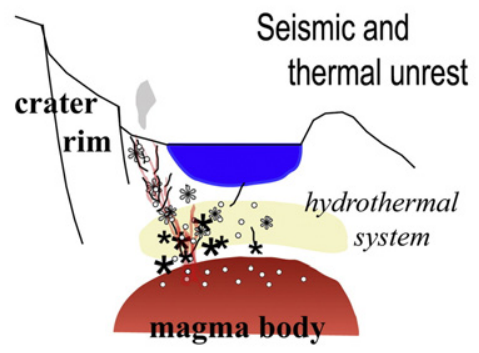

Phase Ic

c)

(Jul - Aug 2005)

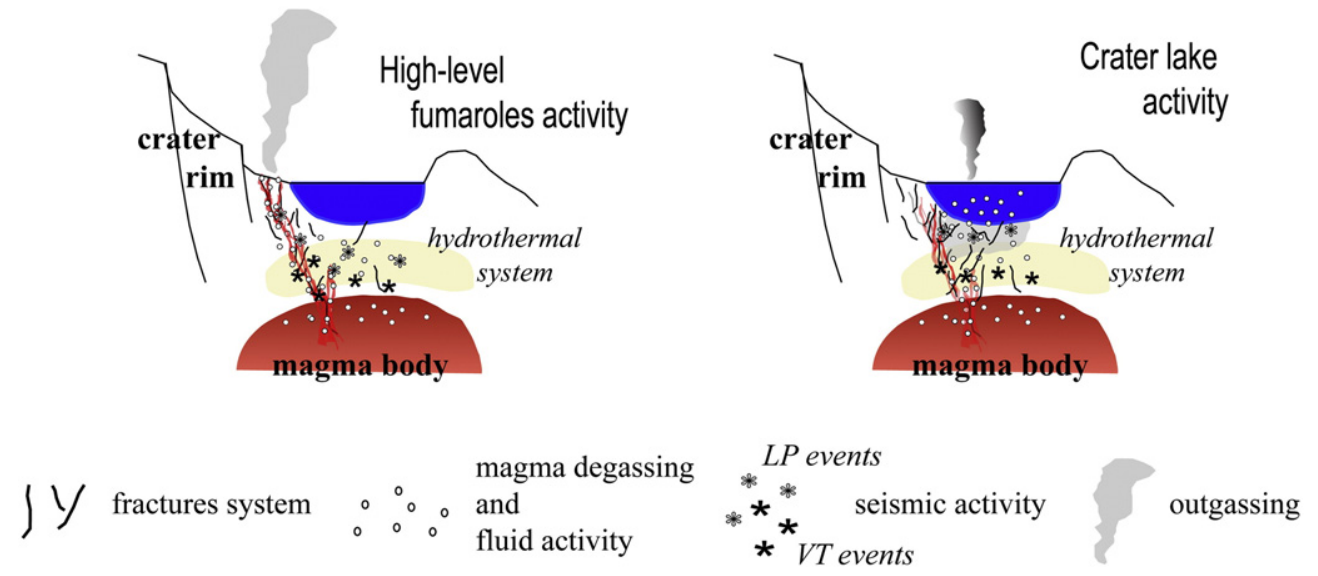

$\int Y$ fractures system $\begin{array}{lll}0 & \text { magma degassing } \\ 0 & 0 & \text { and } \\ & & \text { fluid activity }\end{array}$
Phase II

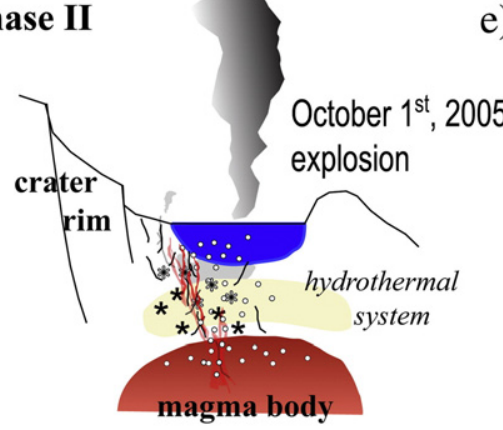

e)

f)

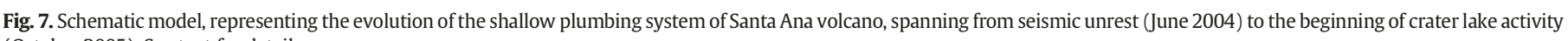
(October 2005). See text for details.

a lava dome extrusions (Connor et al., 1993; Taran et al., 1995; Hutchison et al., 2013), outlining the remarkable support of our space based measurements on the monitoring of active volcanoes.

\section{Conclusions}

The analysis of the MODIS infrared data over Santa Ana volcano re veals that the October 1, 2005 phreatomagmatic eruption has been pre ceded by one year long thermal anomalies associated with the high temperature fumaroles located on the side of the summit crater lake.

By combining satellite thermal data with the geophysical, geochem ical and lake temperature measurements, we identified progressive levels of volcanic unrest preceding the main eruptive event. We linked this scenario with the upward migration of an undegassed magma batch promoting seismic, thermal and outgassing anomalies, which in volved, at different stages, the fumarole field and, finally, the crater lake. Our results demonstrate the capability of the MIROVA system to track volcanic processes that may precede explosive eruptions and/or lava dome extrusions.
We suggest that the integration of satellite thermal data in a ground based monitoring network represents a strategic tool in volcano surveil lance, aimed to forecast eruptions, and mitigate volcanic risk.

Supplementary data to this article can be found online at http://dx. doi.org/10.1016/j.jvolgeores.2017.04.013.

\section{Acknowledgments}

MIROVA is a collaborative project between the Universities of Turin and Florence (Italy), and is supported by the Italian Civil Protection De partment. Additional funds were provided by MIUR, Fondazione Cassa di Risparmio di Torino and Fondazione Compagnia di San Paolo di Torino.

We thank, N. Fournier and G. Chiodini for their constructive com ments and suggestions to improve the quality of this manuscript. We acknowledge the LANCE MODIS system (http://lance modis.eosdis. nasa.gov/) for providing Level 1BMODIS data. Analyses and visualiza tions used in Fig. S1c were produced with the Giovanni online data sys tem, developed and maintained by the NASA GES DISC (http://disc.sci. 


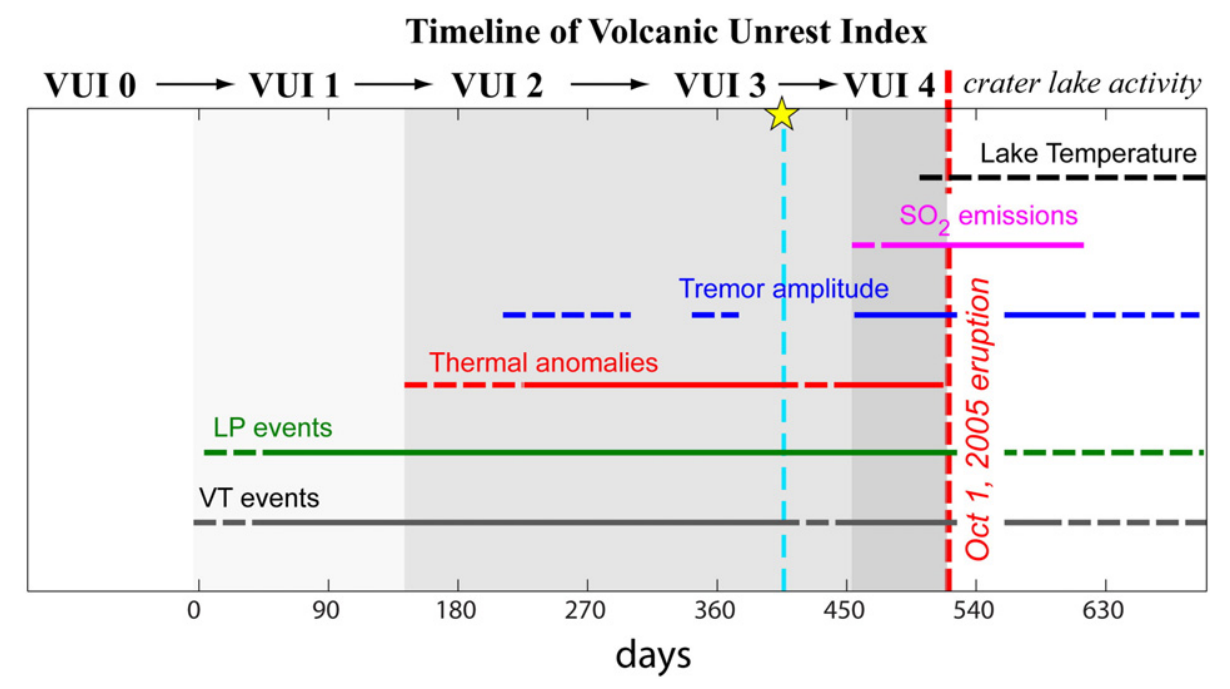

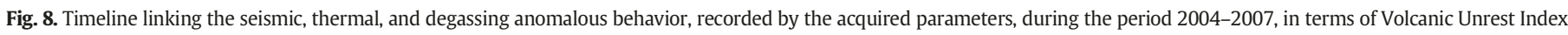
(Potter et al., 2015). Time-series started from Jan 1, 2004 (VUI 0) and the day counting from the beginning of the phase I (VUI 1, see text for details).

gsfc.nasa.gov/). This is the IPGP contribution number: 3839.We thank, N. Fournier and G. Chiodini for their constructive comments and sugges tions to improve the quality of this manuscript. We acknowledge the LANCE MODIS system (http://lance modis.eosdis.nasa.gov/) for provid ing Level 1BMODIS data. Analyses and visualizations used in Fig. S1c were produced with the Giovanni online data system, developed and maintained by the NASA GES DISC (http://disc.sci.gsfc.nasa.gov/). This is the IPGP contribution number: 3839.

\section{References}

Ball, J.L., Calder, E.S., Hubbard, B.E., Bernstein, M.L., 2013. An assessment of hydrothermal alteration in the Santiaguito lava dome complex, Guatemala: implications for dome collapse hazards. Bull. Volcanol. 75:676. http://dx.doi.org/10.1007/s00445-0120676-z.

Barberi, F., Bertagnini, A., Landi, P., Principe, C., 1992. A review on phreatic eruptions and their precursors. J. Volcanol. Geotherm. Res. 52, 231-246.

Bernard, A., Escobar, C.D., Mazot, A., Gutierrez, R.E., 2004. The acid volcanic lake of Santa Ana volcano, El Salvador. In: Rose, W.I., Bommer, J.J., López, D.L., Carr, M.J., Major, J.J. (Eds.), Natural Hazards in El Salvador: Geol. Soc. Amer. Sp. Paper vol. 375: pp. 121-133. http://dx.doi.org/10.1130/0-8137-2375-2.12.

Bodruddoza Mia, M., Nishijima, J., Fujimitsu, Y., 2014. Exploration and monitoring geothermal activity using Landsat ETM + images - a case study at Aso volcanic area in Japan. J. Volcanol. Geotherm. Res. 275:14-21. http://dx.doi.org/10.1016/j.jvolgeores. 2014.02.008.

Cannata, A., Alparone, S., Ursino, A., 2013. Repeating volcano-tectonic earthquakes at Mt. Etna volcano (Sicily, Italy) during 1999-2009. Gondwana Res. 24 (3-4):1223-1236. http://dx.doi.org/10.1016/j.gr.2013.02.012.

Carn, S.A., Clarisse, L., Prata, A.J., 2016. Multi-decadal satellite measurements of global volcanic degassing. J. Volcanol. Geotherm. Res. 311:99-134. http://dx.doi.org/10.1016/j. jvolgeores.2016.01.002.

Carr, M.J., Pointer, N.K., 1981. Evolution of a young parasitic cone toward a mature central vent; Izalco and Santa Ana volcanoes in El Salvador, Central America. J. Volcanol. Geotherm. Res. 11, 277-292.

Casadevall, T.J., Johnston, D.A., Harris, D.A., Rose Jr., W.I., Malinconico Jr., L.L., Stoiber, R.E.,

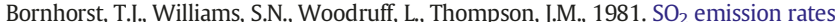
at Mount St. Helens from March 29 through December, 1980. In: Lipman, P.W., Mullineaux, D.R. (Eds.). The 1980 eruptions of Mount St. Helens. U.S. Geol. Surv. Prof. Pap. 1250, 193-200.

Casertano, L., Borgia, A., Cigolini, C., Morales, L.D., Gomez, M., Fernandez, J.F., 1987. An integrated dynamic model for the volcanic activity at Poás volcano, Costa Rica. Bull. Volcanol. 49, 588-598.

Chiodini, G., Vilardo, G., Augusti, V., Granieri, D., Caliro, S., Minopoli, C., Terranova, C., 2007. Thermal monitoring of hydrothermal activity by permanent infrared automatic stations: results obtained at Solfatara di Pozzuoli, Campi Flegrei (Italy). J. Geophys. Res. 112 (B12). http://dx.doi.org/10.1029/2007JB005140.

Chouet, B.A., Matoza, R.S., 2013. A multi-decadal view of seismic methods for detecting precursors of magma movement and eruption. J. Volcanol. Geotherm. Res. 252: 108-175. http://dx.doi.org/10.1016/j.jvolgeores.2012.11.013.

Christenson, B.W., Wood, C.P., 1993. Evolution of the vent hosted hydrothermal system beneath Ruapehu Crater Lake, New Zealand. Bull. Volcanol. 55:547-565. http://dx. doi.org/10.1007/BF00301808.

Christenson, B.W., Reyes, A.G., Young, R., Moebis, A., Sherburn, S., Cole-Baker, J., Britten, K. 2010. Cyclic processes and factors leading to phreatic eruption events: insights from the 25 September 2007 eruption through Ruapehu Crater Lake, New Zealand J. Volcanol. Geotherm. Res. 191:15-32. http://dx.doi.org/10.1016/j.jvolgeores.2010. 01.008 .

Cigolini, C., 2010. The dynamics of a double-cell hydrothermal system in triggering seismicity at Somma-Vesuvius: results from a high-resolution radon survey (revisited). Bull. Volcanol. 72:693-704. http://dx.doi.org/10.1007/s00445-010-0355-x.

Cigolini, C., Gervino, G., Bonetti, R., Conte, F., Laiolo, M., Coppola, D., Manzoni, A., 2005 Tracking precursors and degassing by radon monitoring during major eruptions at Stromboli Volcano (Aeolian Islands, Italy). Geophys. Res. Lett. 32, L12308. http://dx. doi.org/10.1029/2005GL022606.

Colvin, A., 2008. Crater Lake Evolution During Volcanic Unrest: Case Study of The 2005 Phreatic Eruption at Santa Ana Volcano, El Salvador. (MS Thesis). Michigan Technological University, p. 181

Colvin, A., Rose, W.I., Varekamp, J.C., Palma, J.L., Escobar, D., Gutierrez, E., Montalvo, F. Maclean, A., 2013. Crater lake evolution at Santa Ana Volcano (El Salvador) following the 2005 eruption. In: Rose, W.I., Palma, J.L., Delgado Granados, H., Varley, N. (Eds.) Understanding Open-Vent Volcanism and Related Hazards: Geol. Soc. Amer. Sp. Paper vol. 498:pp. 23-43. http://dx.doi.org/10.1130/2013.2498(02).

Connor, C.B., Clement, B.M., Xiaodan, S., Lane, S.B., West, T.J., 1993. Continuous monitoring of high-temperature fumaroles on an active lava dome, Volcán Colima, Mexico: evidence of mass flow variation in response to atmospheric forcing. J. Geophys. Res. 98:19,713-19,722. http://dx.doi.org/10.1029/93JB02169.

Coppola, D., Macedo, O., Ramos, D., Finizola, A., Delle Donne, D., del Carpio, J., White, R. McCausland, W., Centeno, R., Rivera, M., Apaza, F., Ccallata, B., Chilo, W., Cigolini, C., Laiolo, M., Lazarte, I., Machaca, R., Masias, P., Ortega, M., Puma, N., Taipe, E., 2015 Magma extrusion during the Ubinas 2013-2014 eruptive crisis based on satellite thermal imaging (MIROVA) and ground-based monitoring. J. Volcanol. Geotherm. Res. 302:199-210. http://dx.doi.org/10.1016/j.jvolgeores.2015.07.005.

Coppola, D., Laiolo, M., Cigolini, C., Delle Donne, D., Ripepe, M., 2016a. Enhanced volcanic hot-spot detection using MODIS IR data: results from the MIROVA system. In: Harris, A.J.L., De Groeve, T., Garel, F., Carn, S.A. (Eds.). Detecting, modelling and responding to effusive eruptions. Geol. Soc. Lond., Spec. Publ. 426:181-206. http://dx.doi.org/10. 1144/SP426.5.

Coppola, D., Laiolo, M., Lara, L.E., Cigolini, C., Orozco, G., 2016b. The 2008 “silent” eruption of Nevados de Chillán (Chile) detected from space: effusive rates and trends from the MIROVA system. J. Volcanol. Geotherm. Res. 327:322-329. http://dx.doi.org/10.1016/ j.jvolgeores.2016.08.016.

Coppola, D., Laiolo, M., Cigolini, C., 2016c. Fifteen years of thermal activity at Vanuatu's volcanoes (2000-2015) revealed by MIROVA. J. Volcanol. Geotherm. Res. 322:6-19. http://dx.doi.org/10.1016/j.jvolgeores.2015.11.005.

Coppola, D., Ripepe, M., Laiolo, M., Cigolini, C., 2017. Modelling satellite-derived magma discharge to explain caldera collapse. Geology http://dx.doi.org/10.1130/G38866.1.

Dean, K.G., Servilla, M., Roach, A., Foster, B., Engle, K., 1998. Satellite monitoring of remote volcanoes improves study efforts in Alaska. EOS Trans. Am. Geophys. Union 79 (413, 422-423).

Dehn, J., Dean, K.G., Engle, K., Izbekov, P., 2002. Thermal precursors in satellite images of the 1999 eruption of Shishaldin Volcano. Bull. Volcanol. 64 (8):525-534. http://dx. doi.org/10.1007/s00445-002-0227-0.

Fernandez, M., Escobar, D., Redondo, C., 2004. Seismograph Networks and seismic observation in El Salvador and Central America. In: Rose, W.I., Bommer, J.J., López, D.J., Carr, M.J., Major, J.J. (Eds.), Natural Hazards in El Salvador: Boulder. Colorado. Geol. Soc. America Sp. Paper Vol. 375:pp. 257-267. http://dx.doi.org/10.1130/0-8137-2375-2. 257.

Finizola, A., Lénat, J.F., Macedo, O., Ramos, D., Thouret, J.C., Sortino, F., 2004. Fluid circulation and structural discontinuities inside Misti volcano (Peru) inferred from self-potential measurements. J. Volcanol. Geotherm. Res. 135:343-360. http://dx.doi.org/10 1016/j.jvolgeores.2004.03.009. 
Fischer, T.P., Ramírez, C., Mora-Amador, R.A., Hilton, D.R., Barnes, J.D., Sharp, Z.D., Le Brun, M., de Moor, J.M., Barry, P.H., Füri, E., Shaw, A.M., 2015. Temporal variations in fumarole gas chemistry at Poás volcano, Costa Rica. J. Volcanol. Geotherm. Res. 294:56-70. http://dx.doi.org/10.1016/j.jvolgeores.2015.02.002.

Galle, B., Oppenheimer, C., Geyer, A., McGonigle, A.J., Edmonds, M., Horrocks, L., 2002. A miniaturised ultraviolet spectrometer for remote sensing of $\mathrm{SO}_{2}$ fluxes: a new too for volcano surveillance. J. Volcanol. Geotherm. Res. 119 (1):241-254. http://dx.doi. org/10.1016/S0377-0273(02)00356-6.

Global Volcanism Program, 2001. Report on Santa Ana (El Salvador). In: Wunderman, R. (Ed.), Bulletin of the Global Volcanism Network. 26. Smithsonian Institution:p. 4 http://dx.doi.org/10.5479/si.GVP.BGVN200104-343020.

Global Volcanism Program, 2005. Report on Santa Ana (El Salvador). In: Wunderman, R. (Ed.), Bulletin of the Global Volcanism Network. 30. Smithsonian Institution:p. 9 http://dx.doi.org/10.5479/si.GVP.BGVN200509-343020.

Harris, A.J.L., 2013. Thermal Remote Sensing of Active Volcanoes. A user's Manual. Cambridge University Press, p. 736

Harris, A.J.L., Stevenson, D.S., 1997. Thermal observations of degassing open conduits and fumaroles at Stromboli and Vulcano using remotely sensed data. J. Volcanol. Geotherm. Res. 76:175-198. http://dx.doi.org/10.1016/S0377-0273(96)00097-2.

Hernández, P.A., Pérez, N.M., Varekamp, J.C., Henriquez, B., Hernández, A., Barrancos, J., Padrón, E., Calvo, D., Melián, G., 2007. Crater lake temperature changes of the 2005 eruption of Santa Ana volcano, El Salvador, Central America. Pure Appl. Geophys. 164 (12):2507-2522. http://dx.doi.org/10.1007/978-3-7643-8720-4_9.

Hutchison, W., Varley, N., Pyle, D.M., Mather, T.A., Stevenson, J.A., 2013. Airborne thermal remote sensing of the volcán de Colima (Mexico) lava dome from 2007 to 2010 . Geol. Soc. Lond. Spec. Publ. 380 (1):203-228. http://dx.doi.org/10.1144/SP380.8.

Kaneko, T., Wooster, M.J., 1999. Landsat infrared analysis of fumarole activity at Unzen volcano: time-series comparison with gas and magma fluxes. J. Volcanol. Geotherm. Res. 9:57-64. http://dx.doi.org/10.1016/S0377-0273(98)00122-X.

McNutt, S.R., 2000. Volcanic seismicity. In: Sigurdsson, H., Houghton, B.F., McNutt, S.R., Rymer, H., Stix, J. (Eds.), Encyclopedia of Volcanoes. Academic Press, San Diego, pp. 1015-1033.

Mooser, F., Meyer-Abich, H., McBirney, A.R., 1958. Catalogue of the Active Volcanoes of the World and Solfatara Fields of Central America, Part VI: Napoli. Italy, International Volcanological Association (146 pp).

Németh, K., Cronin, S.J., Charley, D., Harrison, M., Garae, E., 2006. Exploding lakes in Vanuatu - "Surtseyan-style" eruptions witnessed on Ambae Island. Episodes 29 (2) $87-92$.

Olmos, R., Barrancos, J., Ivera, C.R., Barahona, F., López, D.L., Henriquez, B., Hernández, A Benitez, E., Hernández, P.A., Pérez, N.M., Galle, B.O., 2007. Anomalous emissions of $\mathrm{SO}_{2}$ during the recent eruption of Santa Ana volcano, El Salvador, Central America. Pure Appl. Geophys. 164 (12):2489-2506. http://dx.doi.org/10.1007/978-3-76438720-4_8.

Oppenheimer, C., 1993. Infrared surveillance of crater lakes using satellite data. J. Volcanol. Geotherm. Res. 55 (1-2):117-128. http://dx.doi.org/10.1016/03770273(93)90093-7.

Oppenheimer, C., 1996. Crater lake heat losses estimated by remote sensing. Geophys. Res. Lett. 23 (14):1793-1796. http://dx.doi.org/10.1029/96GL01591.

Oppenheimer, C., 1997. Remote sensing of the color and temperatura of volcanic lakes. Int. J. Remote Sens. 18 (1):5-37. http://dx.doi.org/10.1080/014311697219259.

Patrick, M.R., Smellie, J.L., Harris, A.J.L., Wright, R., Dean, K., Izbekov, P., Garbeil, H., Pilger, E., 2005. First recorded eruption of Belinda volcano (Montagu Island), South Sandwich Islands. Bull. Volcanol. 67:415-422. http://dx.doi.org/10.1007/s00445-0040382-6.

Phillipson, G., Sobradelo, R., Gottsmann, J., 2013. Global volcanic unrest in the 21st century: an analysis of the first decade. J. Volcanol. Geotherm. Res. 264:183-196. http://dx. doi.org/10.1016/j.jvolgeores.2013.08.004.

Potter, S.H., Scott, B.J., Jolly, G.E., Neall, V.E., Johnston, D.M., 2015. Introducing the Volcanic Unrest Index (VUI): a tool to quantify and communicate the intensity of volcanic unrest. Bull. Volcanol. 77. http://dx.doi.org/10.1007/s00445-015-0957-4.

Pullinger, C., 1998. Evolution of the Santa Ana Volcanic Complex, El Salvador. Michigan Technological University, Houghton (Master thesis: $151 \mathrm{pp}$ ).

Ramsey, M.S., Harris, A.J.L., 2012. Volcanology 2020: how will thermal remote sensing of volcanic surface activity evolve over the next decade? J. Volcanol. Geotherm. Res. 249:217-233. http://dx.doi.org/10.1016/j.jvolgeores.2012.05.011.

Ricci, T., Finizola, A., Barde-Cabusson, S., Delcher, E., Alparone, S., Gambino, S., Miluzzo, V., 2015. Hydrothermal fluid flow disruptions evidenced by subsurface changes in heat transfer modality: the La Fossa cone of Vulcano (Italy) case study. Geology 43 (11) 959-962. http://dx.doi.org/10.1130/G37015.1.
Ripepe, M., Delle Donne, D., Genco, R., Maggio, G., Pistolesi, M., Marchetti, E., Lacanna, G., Ulivieri, G., Poggi, P., 2015. Volcano seismicity and ground deformation unveil the gravity-driven magma discharge dynamics of a volcanic eruption. Nat. Commun. 6 : 6998. http://dx.doi.org/10.1038/ncomms7998.

Rodríguez, L.A., Watson, M.I., Rose, W.I., Branan, Y.K., Bluth, G.J.S., Chigna, G., Matías, O. Escobar, C.D., Carn, S.A., Fischer, T.P., 2004. $\mathrm{SO}_{2}$ emissions to the atmosphere from active volcanoes in Guatemala and El Salvador, 1999-2002. J. Volcanol. Geotherm. Res. 138:325-344. http://dx.doi.org/10.1016/j.jvolgeores.2004.07.008.

Rosas-Carbajal, M., Komorowski, J.C., Nicollin, F., Gibert, D., 2016. Volcano electrical tomography unveils edifice collapse hazard linked to hydrothermal system structure and dynamics. Sci. Rep. 6:29899. http://dx.doi.org/10.1038/srep29899.

Rouwet, D., Tassi, F., Mora-Amador, R., Sandri, L., Chiarini, V., 2014. Past, present and future of volcanic lake monitoring. J. Volcanol. Geotherm. Res. 272:78-97. http://dx. doi.org/10.1016/j.jvolgeores.2013.12.009.

Scolamacchia, T. Pullinger, C. Caballero, L., Montalvo, F, Beramendi Orosco, LE., Gonzalez Hernández, G., 2010. The 2005 eruption of Ilamatepec (Santa Ana) volcano, El Salvador. J. Volcanol. Geotherm. Res. 189 (3-4):291-318. http://dx.doi.org/10.1016/j. jvolgeores.2009.11.016

Servicio Nacional de Estudios Territoriales (SNET), 2005a. Informe Especial n.1: Junio, 16, 2005a, El Salvador. http://www.snet.gob.sv/Geologia/Vulcanologia/evento012005. htm.

Servicio Nacional de Estudios Territoriales (SNET), 2005b. Informe Especial n.2: Junio, 17 2005b, El Salvador. http://www.snet.gob.sv/Geologia/Vulcanologia/evento012005. htm.

Servicio Nacional de Estudios Territoriales (SNET), 2005c. Informe Especial n.5: Agosto 30 , 2005c, El Salvador. http://www.snet.gob.sv/Geologia/Vulcanologia/evento012005. htm.

Servicio Nacional de Estudios Territoriales (SNET), 2017. Informe Mensual de Monitoreo Volcánico, Febrero, 2017, El Salvador. http://www.snet.gob.sv/Geologia/ Vulcanologia/monitoreob.php?id_volcan $=6$.

Shinohara, H., Yoshikawa, S., Miyabuchi, Y., 2015. Degassing activity of a volcanic crater lake: Volcanic plume measurements at the Yudamari crater lake, Aso volcano, Japan. In: Rouwet, D. Christenson, B., Tassi, F. Vandemeulebrouck, J. (Eds.), Volcanic Lakes. Springer, Heidelberg:pp. 201-217 http://dx.doi.org/10.1007/978-3-64236833-2_8.

Simkin, T., Siebert, L., 1994. Volcanoes of the World. Geoscience Press, Tucson, Arizona (349 pp).

Stevenson, J.A., Varley, N., 2008. Fumarole monitoring with a handheld infrared camera: Volcán de Colima, Mexico, 2006-2007. J. Volcanol. Geotherm. Res. 177 (4): 911-924. http://dx.doi.org/10.1016/j.jvolgeores.2008.07.003.

Taran, Y.A., Hedenquist, J.W., Korzhinsky, M.A., Tkachenko, S.I., Shmulovich, K.I., 1995. Geochemistry of magmatic gases from Kudryavy volcano, Iturup, Kuril Islands. Geochim. Cosmochim. Acta 59:1749-1761. http://dx.doi.org/10.1016/00167037(95)00079-F.

Tassi, F., Vaselli, O., Fernandez, E., Duarte, E., Martinez, M., Delgado Huertas, A., Bergamaschi, F., 2009. Morphological and geochemical features of crater lakes in Costa Rica: an overview. J. Limnol. 68 (2):193-205. http://dx.doi.org/10.3274/JL0968-2-04

Trunk, L., Bernard, A., 2008. Investigating crater lake warming using ASTER thermal imagery: case studies at Ruapehu, Poás, Kawah Ijen, and Copahué Volcanoes. J. Volcanol. Geotherm. Res. 178:259-270. http://dx.doi.org/10.1016/j.jvolgeores.2008.06.020.

Valade, S., Lacanna, G., Coppola, D., Laiolo, M., Pistolesi, M., Delle Donne, D., Genco, R., Marchetti, E., Ulivieri, G., Allocca, C., Cigolini, C., Nishimura, T., Poggi, P., Ripepe, M. 2016. Tracking dynamics of magma migration in open-conduit systems. Bull. Volcanol. 78:78. http://dx.doi.org/10.1007/s00445-016-1072-x.

White, R., McCausland, W., 2015. Volcano-tectonic earthquakes: a new tool for estimating intrusive volumes and forecasting eruptions. J. Volcanol. Geotherm. Res. 309: 139-155. http://dx.doi.org/10.1016/j.jvolgeores.2015.10.020.

Williams-Jones, G., Stix, J., Heiligmann, M., Charland, A., Sherwood Lollar, B., Arner, N., Garzon, G., Barquero, J., Fernandez, E , 2000. A model of diffuse degassing at three subduction related volcanoes. Bull. Volcanol. 62, 130-142.

Zobin, V.M., Varley, N.R., González, M., Orozco, J., Reyes, G.A., Navarro, C., Bretón, M., 2008. Monitoring the 2004 andesitic block-lava extrusion at Volcán de Colima, México from seismic activity and $\mathrm{SO}_{2}$ emission. J. Volcanol. Geotherm. Res. 177:367-377. http://dx. doi.org/10.1016/j.jvolgeores.2008.05.015. 